\title{
Syrian Refugees in Jordan: Burden or Boon
}

\author{
Nafez Ali $^{1} \&$ Saeb F. Al Ganideh ${ }^{1}$ \\ ${ }^{1}$ Faculty of Business, Al Zaytoonah University of Jordan, Amman, Jordan \\ Correspondence: Saeb F. Al Ganideh, Faculty of Business, Al Zaytoonah University of Jordan, PO box 130, Amman \\ 11733, Jordan.E-mail: saeb@zuj.edu.jo
}

Received: December 15, 2019

Accepted: February 3, 2020

Online Published: March 14, 2020

doi:10.5430/rwe.v11n1p180

URL: https://doi.org/10.5430/rwe.v11n1p180

\begin{abstract}
The growing number of Syrian refugees in Jordan broadens the importance of exploring Jordanians' attitudes toward increasingly protracted Syrian refugees. The purpose of this study is to examine the extent to which demographic and socio-psychological variables shape Jordanians' attitudes toward Syrian refugees. The study design is mainly quantitative with a qualitative technique to support and expand upon the study findings. Data were collected from 199 Jordanians over a sixteen-week period in 2015. Quantitative data were analyzed using a hierarchal regression method. The results reveal that attitudes toward Syrian refugees in Jordan are determined by issues such as unemployment and pressure on resources. Income, geographical location and patriotism were found to have statistically significant influence on Jordanians' attitude toward Syrian refugees. Jordanians who live in the North of the country (large number of Syrian refugees reside in this area), high income Jordanians, and Jordanian with high level of patriotism hold the least positive attitudes toward Syrian refugees.
\end{abstract}

Keywords: Syrian refugees, Jordan's economy, unemployment, Arab Spring

\section{Introduction}

\subsection{Background}

Civil wars accompanied by foreign interventions caused the largest number of forcibly displaced people (Schmeidl, 1997). International migration researchers agreed that violence is the key factor that forces individuals to abandon their livelihoods and seek refuge in other countries (Moore and Shellman, 2007). It is hard to understand the far-reaching impacts of armed civil conflict on societies. Nonetheless, the human suffering and damaging economic consequences inflicted by civil wars and internal conflicts are evident to all (Baez, 2011). The sudden inflow of a large refugee population in developing countries, could potentially strain the economic infrastructures of hosting countries (Kreibaum, 2016). Hosting protracted refugees lead to economic, security, social, and environmental problems within hosting societies (Jacobsen, 2002). In general, research on refugees focused mainly on displaced refugees and did not give high attention to individuals who live in communities that hosted refugees, particularly in developing countries have difficulties providing for their own people (Alix-Garcia and Saah, 2010; Baez, 2011; Doocy et al., 2011; Kreibaum, 2016). The Arab Spring created global migrant crisis that influenced the Middle East and Europe (Fargues and Fandrich, 2012). The Syrian conflict forced more than four million people to flee their homes toward neighboring countries while more than seven million Syrians have been internally displaced within Syria (Cumming-Bruce, 2015). Many countries all over the Middle East and Europe, including Jordan, Lebanon and Turkey are coping with increasingly protracted Syrian refugees. Almost two million Syrians fled to Europe; the highest number of refugees since the collapsed of Third Reich in 1945 (Cohen, 2015). Jordan received more than 650,000 Syrian refugees in the years between 2010 and 2015 (UNHCR, 2016). There is a dearth of empirical research when it comes to exploring locals' attitudes toward Arab Spring refugees' influence on hosting communities. The current study build on previous international migration literature by examining Jordanians' attitudes toward increasingly protracted Syrian refugees and how their attitudes are determined by demographic variables (income, geographical location, and gender) and socio-psychological variables (patriotism, religious commitment, and internationalism).

\subsection{Arab Spring's Refugees}

Despite the Arab Uprising events almost extended to every single Arab country at different level of activities, the Syrian civil war has marked and changed the face of the Arab Spring from a call for more dignity (Trabelsi, 2014) to 
a brutal sectarian conflict and war (Al Ganideh and Good, 2015) and resulted in worst refugee crisis since World War II (Cumming-Bruce, 2015). The sectarian dispute between Sunni and Shaite Arab countries added to the brutality of the Arab Spring and the Syrian civil war (Guzansky and Berti, 2014) and forced millions of Syrians to flee their country. António Guterres, the UN's High Commissioner for Refugees clarified the brutality of the Syrian conflict by stating that:

Syria has become the great tragedy of this century - a disgraceful humanitarian calamity with suffering and displacement unparalleled in recent history, and the only solace is the humanity shown by the neighboring countries in welcoming and saving the lives of so many refugees (UNHCR, 2013).

The Arab Spring events influenced Arab countries' economies, including Jordan, and added more struggling, poverty, and unemployment to most Arabs and particularly to children and women (Al Ganideh and Good, 2015; Bayat, 2015). Hundreds of thousands of Syrians who fled their country to neighboring small kingdom of Jordan created a major demographic shift in the small country and added to Jordan's economic and unemployment problems. The very complex and dramatic nature of the Syrian crisis influenced negatively both Syrian refugees who fled to Jordan and local Jordanians (Achilli, 2015). Al-Kilani (2014) indicated that Jordan Government considers any Syrian national who crosses the $378 \mathrm{~km}$ Jordan-Syrian border and gets to Jordan from one of 48 refugee recognized crossing pointes a welcomed refugee. In the same light, Al-Kilani (2014: 30) stated that 'Jordan's law on refugees is defined by a 1998 Memorandum of Understanding with UNHCR, amended in April 2014. It includes the Convention's definition of 'refugee' and accepts the principle of non-refoulement and third country resettlement for refugees.' About 80 percent of Syrian refugees in Jordan live in urban areas in the north of the country (UNHCR, 2016).

The majority of Syrian refugees in Jordan do not live in camps. Small percentage of Syrian refugees who fled to Jordan reside in camps, for example, about 80,000 Syrian refugee live in Zaatari Camp (UNHCR, 2016). This number makes Zaatari camp as the fourth largest city in Jordan. The presence of Syrian refugees in the country not only caused sharp increase in housing and rental prices but also resulted in extreme pressure and demand on basic services such as schooling, security, water, housing, food, health care, and energy and water (Achilli, 2015; Al-Kilani, 2014; Haddadin, 2016). For example, the Syrian refugees created a real pressure on Jordanian health care system with the increase of workload on staff, the appearance of eradicated diseases (require vaccination), and the lower operational age of medical equipment (The Jordan Times, 2016). The free medical care and treatment offered to Syrian refugees in Jordan cost the Jordanian Government about 2 billion USD since the beginning of the Syrian civil war in 2012 (Haddadin, 2016). According to Achilli (2015), the protracted nature of the Syrian crisis and its negative impact on Jordan's economy and Jordanians' living conditions have changed the positive mode of some Jordanians toward Syrians to become hostile. There is an increasing belief among some segments of the Jordan's society that Syrians' refugees are competing locals on their country limited resources. Competition on jobs represent a clear point of friction between locals and Syrian refugees (Achilli, 2015; Al-Kilani, 2014). Understanding Syrian refugees' impact on their host societies, including the key drivers of host community tensions, in Jordan, is vital as that could offer policymakers in these countries with a clearer view of the impact of mega Syrian refugee influx into communities from a local perspective.

\subsection{Jordan: Long History With Protracted Refugees}

Jordan has the second largest number of refugees per capita worldwide (UNHCR, 2014). The country is host to the largest number of Palestinian refugees who reside in any single country (Chatelard, 2010). Despite half of Jordan's 6 million inhabitants are Palestinian refugees, only 634,182 of them are registered officially as refugees (Lischer, 2008). Most of the Palestinians in Jordan were granted citizenship (Fagen, 2009). Despite Palestinian refugees in Jordan have free access to public schooling, wide range of job opportunities, and free movement (with Jordanian's official travel documents), there are clear differences in life standards between those who live in camps and those who live out camps (Khawaja, 2003). Unlike other Arab countries, such as, Egypt, Iraq, Lebanon, and Syria which offer Palestinians special refugee travel documents and residency permits, Jordan was the only Arab country to grant Palestinian refugees Jordanian citizenship (Shiblak, 1996). However, since fleeing to Jordan in 1948, Palestinian refugees have played a significant role in Jordan's economic and educational development (Chatelard, 2010). For example, unlike Jordan, Palestinian refugees in Lebanon have suffered from social exclusion, poverty and unemployment for decades.

The American war against Iraq in 2003 caused a dramatic shift in power in the country between Sunni and Shaite Iraqi Muslims and forced large number of Sunnis to flee Iraq to neighboring Jordan (Fagen, 2009). Jordan welcomed displaced Iraqi refugees almost with not restrictions despite the constant influx of Iraqi refugees to the country influenced its scarce resources (Al-Qdah and Lacroix, 2011). Iraqis have been perceived, in Jordan, as guests rather 
than as refugees. Indeed, the Jordanian Government neither established camps for Iraqis nor granted them refugee status (Lischer, 2008). Unofficial reports estimate the number of Iraqis in Jordan between 750,000 to 1 million (i.e., Al-Qdah and Lacroix, 2011; De Bel-Air, 2009). This estimated number is far away from the official number of 130,911 Iraqis live in Jordan (JDOS 2016). The vast majority of Iraqis in Jordan reside in the capital of Jordan, Amman city, and their massive presence at some areas of the city has led to a sharp increase in rental and real estate prices (Fagen, 2009). Despite the vast majority of Iraqis who fled to Jordan were wealthy and well-educated, hosting them limited the rate of economic growth (Doocy et al., 2011). These implications forced the Jordanian government to be less tolerant with incoming Iraqis after the year 2007 (Al-Qdah and Lacroix, 2011).

\subsection{Theoretical Background}

The integrated threat theory could represent a good theoretical background for locals' attitudes toward refugees (Schweitzer et al., 2005). The integrated threat theory suggests two basic types of threat namely, realistic (related to out-group materialism power and resources) and symbolic (spiritual issues such as religion and belief system) (Stephan and Mealy, 2011; Stephan and Renfro, 2002). Intergroup anxiety and negative stereotyping are also considered as threats implies by the integrated threat theory (Stephan and Renfro, 2002). Negative stereotypes were considered originally as a distinct sort of threat, later it has been considered as a threat that affects realistic and symbolic types of threat and leads to negative sentiment toward out-groups (Stephan and Mealy, 2011).

One of the main problems that influences refugees' new lives in their host communities is their high expectations about the new life, mainly about economic and occupational opportunities (Stein, 1986). There is a debate between politicians, researchers, and public about the economic benefits/burdens refugees cause to a hosting community. Generally, competition for resources between host communities and refugees creates anti-refugee sentiments (Martin, 2005). Jacobsen (2002) indicated that despite refugees cost host communities of extra living, health, and security burdens, refugees' influx bring to host countries significant flow of economic assets. Nonetheless, research on refugees and host communities agreed that refugees' influx to a particular area would result on a considerable stress on natural resources and might increase poverty levels in host communities (Black and Sessay, 1997; Jacobsen, 2002; Martin, 2005). For example, earlier, in Sudan, Eritrean and Ethiopian refugees are perceived 'to pose an enormous strain on the fragile Sudanese economy, infrastructure and environment and are blamed for growing hardships' (Ek and Karadawi, 1991:196). Providing refugee camps with sufficient resources from the host community adds to the cost of hosting refugees (De Montclos and Kagwanja, 2000).

Security threats motivate refugees' hosting countries to tighten security level next to frontier and border areas (Jacobsen, 2002). Many traditional western refugees' receiving communities seek to limit refugees' influx as these communities express serious concerns that refugees pose a significant risk to national economy and security (Jacobsen, 2002). According to Jacobsen (1996), the response to the refugee influx varies significantly among countries. While some countries welcome refugees, other countries deal with refugees' influx in a strict manner. Similarly, individuals seek refuge in some countries rather than others due to fear of persecution, wages, culture, and transaction costs of relocation (Moore and Shellman, 2007). There are set of factors that influence refugees' receiving societies general policies regarding receiving or not fled refugees such as the costs and benefits of accepting international assistance, relations with the sending country, political calculations about the local community's absorption capacity, and national security considerations' (Jacobsen, 1996:655). Kreibaum (2016) examined the impact that a refugee population has on its host country and concluded that despite locals who are living near displaced refugee settlements benefit from public service provision for refugees, they complained about the negative impact of refugees on their economic situation.

The international forced migration literature agreed that host groups with better resources benefit from large-scale influxes of refugees, while other host groups with limited resources become more vulnerable as a result of intense competition with refugees (Mabiso et al., 2014). In general, refugees cause food prices to raise due to increased demand (Zetter, 2012). Rising food prices take a devastating impact on poor refugees and locals (Alix-Garcia et al., 2012). International refugee scholarship focused more on displaced refugees rather than host groups (i.e., Neumayer, 2004; Neumayer, 2005; Moore and Shellman, 2007). In addition, refugee literature focused on refugees who fled to developed countries (i.e., Neumayer, 2004; Neumayer, 2005). A number of scholars explored the influence of civil wars and conflicts on internally displaced persons (i.e., Alix-Garcia et al., 2012). Recently, scholars have started to give more attention to the influence of refugees on host communities (i.e., Baez, 2011; Kreibaum, 2016; Mabiso et al., 2014). This research builds on previous research and contribute to the literature by exploring the influence of large-scale influxes of refugees on host communities from the perspective of locals. The negative impact of displaced refugees on local economy can be more noticeable in developing countries (Kreibaum, 2016). Risks of large influx 
of refugees on host communities include disease outbreaks, pressure on health care facilities, food scarcity, crime, labor competition and crowded schools (Baez, 2011). In spite of the significance of the issue, empirical research on host groups' attitudes toward Arab Spring refugees is almost nonexistent. Most of the existing research on Arab Spring refugees has been concentrated on refugees themselves. The current study contributes to understanding host community members' attitudes toward displaced refugees. Specifically, the study explores Jordanians' attitudes toward increasingly protracted Syrian refugees. In addition, it examines the extent to which demographics (income, geographical location, and gender) and socio-psychological variables (patriotism, religious commitment, and internationalism) shape Jordanians' attitudes toward Syrian refugees.

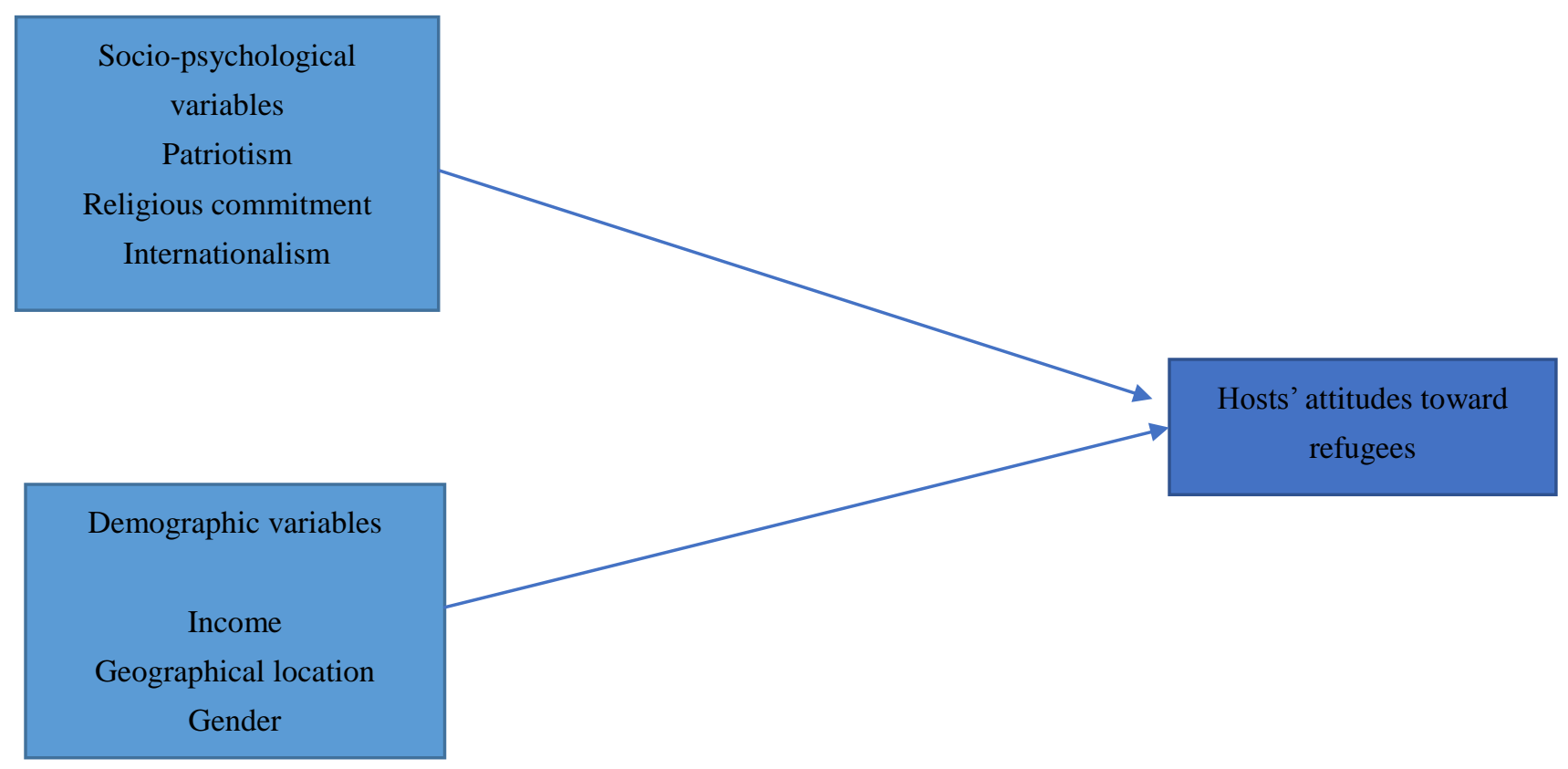

Figure 1. Study model

\subsubsection{Patriotism and Attitudes Toward Refugees}

Earlier, Sumner (1906:15) defined patriotism as 'loyalty to the civic group to which one belongs by birth or the other group bond. It is a sentiment of fellowship and cooperation in all hopes, works, and suffering of the group'. According to Kosterman and Feshbach (1989), patriotism represents the extent to which the individuals are attached to their nation. Patriotism usually denotes loyalty to and love for one's own country. Patriotism refers to one's strong loyalty, love, and sacrifice for one's nation and its interests (Druckman, 1994). Mummendey et al. (2001) showed that high level of patriotic sentiments lead to out-group members' rejection. High level of national identity is a significant predictor of negative attitudes toward refugees and asylum seekers (Pedersen et al., 2005). Generally, patriotic sentiment is a strong positive determinant of attitudes toward refugees (O'rourke and Sinnott, 2006). Anti-refugee literature review concluded that individuals who are more strongly connected to their country, tend to hold less favorable attitudes toward refugee (Haslam and Pedersen, 2007). Thus it is hypothesized that:

Hypothesis 1: Individuals will high level of patriotic sentiments express higher levels of negative attitudes toward refugees.

\subsubsection{Religious Commitment and Attitudes Toward Refugees}

Religion has been ignored as a key variable that determines attitudes toward immigrants and refugees (Knoll, 2009). Despite religion has a significant influence on individuals' lifestyle and their attitudes toward out-groups, previous research on the relationship between religiosity and attitudes toward refugees is nonexistent (Rahman, 2012). In general, strong religious identity motivates people of in-groups to engage in inhumane and improbable actions against other out-groups (Druckman, 1994). For example, Muslim refugees (out-group) have been perceived in Australia as a threat for national identity and security (McKay et al., 2012). Despite Bangladesh is a very poor country, it receives most Arakani refugees due to religious resemblance (Ullah, 2011). 
Religious commitment is an aspect that affects people attitudes toward people from the out-groups (Rahman, 2012). Individuals with strong religious attachment are more likely to perceive out-group as a threat to in-group and its interests (Schlueter and Scheepers, 2010). There is a positive correlation between religiosity and prosociality (Batson et al., 2005; Saroglou, 2006). Against to this notion, Duriez (2004) concluded that religious people do not feel more empathy toward people in need. Islam encourage Muslims to help other Muslims and to save their lives. According to Verkuyten (2007:346) 'The more strongly Muslims identify with their religious in-group, the more likely they are to consider it important to express and preserve their own religion and to participate as religious group members in social and political life' Thus it is anticipated that:

Hypothesis 2: Individuals with higher levels of religious commitment will express lower levels of negative attitudes toward refugees.

\subsubsection{Internationalism and Attitudes Toward Refugees}

International mindedness refers to interest in or knowledge about international affairs and emotional support for people from other countries and cultures (Sampson and Smith, 1957). International mindedness is 'a part of the continuum that represents the self-development and it represents the most complex development of the relationship between the self and other' (Skelton, 2015: 75). According to Arnett (2002:774) indicated that globalization shapes people's minds by developing 'a bicultural identity that links their local identity with an identity linked to the global culture' Globalization has opened physical and social borders worldwide due to ideological shifts in global politics, technological innovations, and the emergence of new communication tools (Türken and Rudmin, 2013). Internationalism represents openness and empathy for individuals from other cultures and emotional support for international sharing and welfare (Kosterman and Feshbach, 1989; Lee et al., 2003). Internationalists express low negative sentiments towards out-groups (Kosterman and Feshbach, 1989). Internationalism entails preference for emotional international support, welfare, cooperation and unity (Karasawa, 2002). Internationalist feelings and globalization open a wide range of options for in-groups and allow almost infinite ways of for groups to identify with each other (Türken and Rudmin, 2013). Consistent with such arguments, we posit a negative relationship between internationalism and attitudes toward refugees. Based on these arguments, it is anticipated that:

Hypothesis 3: Internationalist individuals will express lower levels of negative attitudes toward refugees.

\subsubsection{Income and Attitudes Toward Refugees}

It is vital to understand how mass influxes of refugees could influence host community economic conditions and how hosts' attitudes toward displaced refugees are influenced by hosts' income level. Hosts' attitudes toward refugee presence differed based on income, and wealthy hosts, generally, get benefit of economic opportunities and increase their wealth as a result of refugee influx (Whitaker, 2002). The influx of refugees offers locals employment opportunities with international relief organizations (Landau, 2004). Despite refugees constitute a large supply of low-skilled labor that benefits entrepreneurs, local low-skilled workers are more likely to suffer due to refugees (Mabiso et al., 2014). Creating restrictions on refugees' income generating activities force refugees to compete hosts illegally for waged jobs (Landau, 2004). Low income host community members are negatively affected by a large number of displaced people (Kreibaum, 2016). Disadvantaged locals are usually marginalized by refugee presence, however, individuals who have access to resources benefit from the presence of the refugees (Whitaker, 2002). Refugees are perceived as a threat to local resources in times of economic hardship by hosts (Murray and Marx, 2013). Although, many hosts profit from job opportunities and rise in income as a result of refugee presence, workers on fixed incomes suffer significantly due to cost of living raise (Whitaker, 2002). Recently, Boeshaar (2016) concluded that there is a statistical significant relationship between hosts' level of income and positive attitudes toward refugees. Thus, it is anticipated that:

Hypothesis 4: High income individuals will express lower levels of negative attitudes toward refugees.

\subsubsection{Geographical Location and Attitudes Toward Refugees}

Attitudes toward refugees are shaped based on personal values, and it less likely, for attitudes toward refugees and asylum seekers, to be formed through personal experience (Pedersen et al., 2005). Crawley et al. (2013) concluded that geographical location predicts attitudes toward refugees and people living in cities display the most tolerant views toward refugees. Individuals living in the surrounding regions of refugee and asylum seekers settlements hold more negative views toward refugees and their economic contribution to the local region (Kreibaum 2016). Against to this view, Agblorti (2011) indicated that the influx of refugees and resources to a particular geographic region might create a massive structural positive change into an urban space that even attract people from hosting communities to move there. Displaced refugees to neighboring countries mostly settle in border area, and that forces 
hosting governments to increase security which means extra cost for local communities (Jacobsen, 2002). On this point, Kreibaum (2016) found that although hosting communities might get benefit from additional funding (local and external) and infrastructure's improvement, many people within hosting communities complain about refugees' overall negative influence on local economy and their daily lives (e.g. security threat, disease outbreaks, wage competition, food scarcity, shortage of drinking water). Thus, it is hypothesized that:

Hypothesis 5: Individuals who live in areas with a high density of refugees will express higher levels of negative attitudes toward refugees.

\subsubsection{Gender and Attitudes Toward Refugees}

Gender is a significant predictor of negative attitudes toward refugees and asylum seekers and men hold more negative attitudes toward refugees than women (Pedersen and Walker, 1997). Nonetheless, there is a lack of empirical research little about how refugees impact genders within the host country (Whitaker, 2002). Pedersen et al. (2005) concluded that being male predicts negative attitudes toward refugees and asylum seekers (Pedersen et al., 2005). Women express more favorable attitudes toward refugees than men (Schweitzer et al., 2005). This could be attributed to that 'women are less able that men to gain access to beneficial opportunities created by a refugee situation' (Whitaker, 2002: 345). Against to this notion, Boeshaar (2016) found that hosts' attitudes toward refugees and immigrants do not differ by gender, however, women are more tolerant toward ethnicities than men (Boeshaar, 2016). Based on these argument, it is hypothesized that:

Hypothesis 6: Males will express higher levels of negative attitudes toward refugees than females.

\section{Method}

The current study design is mainly quantitative with a qualitative technique to support and expand upon the study findings. The greater weight in this study was given to the quantitative approach. This study uses a combination of quantitative and qualitative approaches, taking into consideration the benefits and drawbacks of the two approaches and the study objectives. Adopting triangulation reduces the bias in this study, produces more reliable results and increases the accuracy and the validity of the results of the study (Collis and Hussey, 2013; Ghauri and Gronhaug, 2002).

\subsection{Study Context: Jordan}

Jordan is an ideal context for the current empirical research due to a number of reasons: First, Jordan is a good representative country of the Middle East. Second, Jordan is economically and culturally different from countries used in previous empirical studies. Third, Jordan hosts second largest number of refugees per capita worldwide.

Due to difficulties of obtaining a representative sample in Jordan, a convenience sample was drawn from 191 subjects who live in Amman and Irbid Governorates via a questionnaire over a sixteen-week period in 2015. Moreover, a total of 8 semi-structured face-to-face interviews were conducted with Jordanian subjects (5 males and 3 females). Four facilitators (two males and two females) who hold post-graduate degrees in humanities helped in data collection. Participation in the study was absolutely voluntary and no incentives were given to subjects to respond. Two facilitators collected data from subjects who live in Amman Governorate (Al Jubaiha and Abu Nsair) and the other two facilitators collected data from subjects who live in Irbid Governorate (Irbid city and Al Ramtah). Data were collected from subjects in various locations in the two Governorates such as shopping malls (Sahara Mall in Amman, Arabella Mall in Irbid), coffee shops (Al Jubaiha Street in Amman and University Street in Irbid), and homes (Shafa Badran area in Amman and Aiydon and Al Ramtha areas in Irbid). The questionnaire was written originally in English. The researchers adopted parallel translation technique to translate the questionnaire from English to Arabic. Two PhD holders who are native in Arabic and fluent in English translated questionnaire's items from English to Arabic in two focus group meetings.

Eight semi-structured face-to-face personal interviews were conducted (each interview lasted about 30 minutes). Interviews were conducted at a convenient place and time for the interviewees. The facilitators advised a number of subjects (while distributing the questionnaires) if they are willing to participate in a face-to-face interview for a maximum of 45 minutes regarding the positive and negative contributions for Syrian refugees to Jordan's society. Participants were asked the following questions: (a) what are the main positive contributions, for Syrian refugees, to Jordan, and (b) what are the main negative contributions, for Syrian refugees, to Jordan's society. Details of the conducted interviews' participants are shown in Table 1.

\subsection{Participant (Subject) Characteristics}

The demographic characteristics of the subjects, generally, were close to Jordanian population averages. Among the 
respondents, 59.7 percent were male and 40.3 percent were female. The sample is fairly young which is consistent with total Jordan's population. Approximately, 75 percent of the sample age is less than the age of 36. Regarding education, the sample was relatively well-educated with only 21 percent of the sample's educational level is high school or less, while 78.5 percent of subjects hold at least bachelor degree. About two-thirds of the sample are from Amman Governorate, and one-third of the subjects live in Irbid Governorate. The analysis of total monthly income of respondents showed that the sample consists of four main segments: 14.1 percent earn less than 500 USD monthly, 47.6 percent of subjects' income range between 500 USD-1100 USD per month, 22.2 percent of the respondents' monthly income range between 1100USD-1680 USD, and 15.3 percent of the respondents' monthly income exceeds 1680 USD.

Table 1. Face-to-face personal interviews' details

\begin{tabular}{cccccc}
\hline Name* & Age & Gender & Location & Place & Duration (minutes) \\
\hline Sammer & 40 & Male & Amman & coffee Shop & 32 \\
Liana & 31 & Female & Amman & Shopping Mall & 29 \\
Eyad & 47 & Male & Amman & Home & 24 \\
Kamal & 70 & Male & Irbid & Home & 34 \\
Khaled & 39 & Male & Irbid & Coffee Shop & 31 \\
Fareeda & 65 & Female & Irbid & Home & 30 \\
Dana & 24 & Female & Irbid & Shopping Mall & 28 \\
Tamim & 35 & Male & Irbid & Coffee Shop & 33
\end{tabular}

* All names are pseudonyms

\subsection{Measures}

\subsubsection{Attitudes Toward Syrian Refugees}

Subjects were asked to answer 5 items (5-point Likert scale) originally developed by Wilson (2001) and Meertens and Pettigrew (1997) to measure Jordanians' attitudes toward Syrians refugees and their perceptions of threatened group interest. The five items were: Syrians have jobs that Jordanians should have; the Jordan Government care too much about Syrians and not enough about the average Jordanian; Syrian refugees get much help from the government of Jordan; the large number of Syrians in Jordan influences the country's national unity; hosting large number of Syrians has influenced Jordan's economy negatively.

\subsubsection{Patriotism}

To measure Jordanians' patriotism level, five items (5-point Likert scale) developed by Kosterman and Feshbach (1989) were used. The items include: I love my country (Jordan); I am proud to be Jordanian; In a sense, I am emotionally attached to my country and emotionally affected by its actions; although at times I may not agree with the government, my commitment to Jordan always remains strong; I feel a great pride in that land that is our Jordan.

\subsubsection{Religious Commitment}

Two items (5-point Likert scale) originally developed by Worthington et al. (2003) were modified and used to measure Jordanians' Islamic religious commitment. The used two items were: I work hardly on increasing my Islamic knowledge; Islam controls all my daily life issues.

\subsubsection{Internationalism}

To measure Jordanians' internationalism level, four items (5-point Likert scale) developed by Kosterman and Feshbach (1989) were used. The items include: The alleviation of poverty in other countries is their problem, not ours; Jordan should be more willing to share its wealth with other suffering nations, even if it doesn't necessarily coincide with our political interests; I would not be willing to decrease my living standard by $10 \%$ to increase that of persons in poorer countries of the world; Children should be educated to be international-minded to support any movement which contributes to the welfare of the world as a whole, regardless of special national interests. 


\subsubsection{Attitudes Toward Syrian Refuges' Contribution to Jordanian Society}

Subjects were asked an open question to indicate the main positive contributions, for Syrian refugees, to Jordan's society (based on subjects' personal experience). Also, they were asked to state the main negative aspects and contributions, for Syrian refugees, to Jordan.

\subsubsection{Demographics}

Subjects were asked questions regarding their income, geographical location, and gender.

\section{Discussion and Conclusions}

The current study explores Jordanians' attitude toward protracted Syrian refugees. Specifically, the study examines the effects of demographic variables (income, geographical location, and gender) and socio-psychological variables (patriotism, religious commitment, and internationalism) on Jordanians' attitude toward Syrian refugees.

In summary, the measures exhibited acceptable levels of reliability and validity. Cronbach's alphas $(\alpha)$ and correlation coefficients for the measures in this study are depicted in Table 2. All measures yielded Cronbach's alphas greater than 0.60. Alphas ranged from 0.60-0.93. Often 0.60 is recommended as a minimum acceptable standard for reliability (Hair et al., 2006).

Table 2. Correlation matrix of the used measures

\begin{tabular}{lccccc}
\hline \multicolumn{1}{r}{ Measure } & \multicolumn{1}{c}{$\alpha$} & \multicolumn{1}{c}{1} & 2 & 3 & 4 \\
\hline (1) Attitudes toward refugees & 0.60 & 1.00 & & & \\
(2) Patriotism & 0.92 & $0.19^{*}$ & 1.00 & & \\
(3) Religious commitment & 0.76 & 0.05 & $0.27^{* *}$ & 1.00 & \\
(4) Internationalism & 0.93 & -.010 & $0.27^{* *}$ & $0.18^{*}$ & 1.00 \\
\hline
\end{tabular}

Notes. $* P<0.05$ (2-tailed). $* * P<0.01$ level (2-tailed)

Descriptive analysis was conducted to provide general background information and to identify the mean, standard deviation and the percentages of subjects agreeing/disagreeing on each of the items that have been developed to measure Jordanians' attitude toward Syrian refugees (Table 3). The results show that almost $75 \%$ of the subjects believe that Syrian refugees take jobs away from Jordanians. The impact of Syrian refugees on the local economy is perceived as negative by, approximately, half of the Jordanian respondents who believe that Syrian refugees have a negative effect on their own country's economy.

Table 3. Jordanians' attitude toward Syrian refugees

\begin{tabular}{lccccc}
\hline Item & Mean & SD & Agree & Neutral & Disagree \\
\hline $\begin{array}{l}\text { Syrians have jobs that Jordanians should have } \\
\text { Hosting large number of Syrians has influenced Jordan's }\end{array}$ & 3.94 & 1.17 & $74.8 \%$ & $12.0 \%$ & $13.1 \%$ \\
economy negatively & & 1.26 & $47.6 \%$ & $25.7 \%$ & $26.7 \%$ \\
$\begin{array}{l}\text { Syrian refugees get much help from the government of Jordan } \\
\text { The large number of Syrians in Jordan influences the country }\end{array}$ & 3.28 & 1.23 & $42.4 \%$ & $33.0 \%$ & $24.6 \%$ \\
national unity & & 1.12 & $31.9 \%$ & $34.0 \%$ & $34.0 \%$ \\
Jordan's Government care more about Syrians rather than & 2.57 & 1.30 & $23.0 \%$ & $23.6 \%$ & $53.4 \%$ \\
Jordanians & & & & & \\
\hline
\end{tabular}

In essence, the results of the semi-structured face-to-face personal interviews matched the survey's results that Jordanians believe that the economic impact of Syrian refugees on their own country's economy is negative on net. In this regard, one of the interviewees stated that 'Syrians are more preferred than Jordanians in most businesses; they are better in service, cheaper, and agree to work longer hours; ah ah that means local young males are in big problem 
(stopped 5 seconds); no jobs ...no money!' (Khaled, 39, Irbid). In the same light another interviewee argued that 'Syrian refugees caused a real problem for Jordanian workers as they agree to work long hours for less wages; employers prefer them and now locals struggle so much to get a job; Syrians also are more controllable than locals' (Sammer, 40, Amman). This finding agrees with Achilli's (2015) conclusions that intense competition for limited resources between Jordanians and displaced Syrian refugees exacerbates anti-refugee (Syrian) sentiments in Jordan.

A hierarchal regression method was carried out to investigate the joint influence of patriotism, religious commitment and internationalism on Jordanians' attitudes toward Syrian refugees over and above that accounted for by the demographics (Income, geographic location, and gender). In this procedure, predictor variables were entered in two blocks, with demographics entered first to provide a baseline for the model, and then, patriotism, religious commitment and internationalism were entered in the second block. All hypotheses were tested by hierarchical regression analysis, and to provide support for each hypothesis, an inspection of sign and significance of regression weighs for each individual hypothesis was performed.

Table 4 shows that, the first model, when only demographic variables (income, geographical location, and gender) were entered, in the first block, as predictors of Jordanians' attitudes toward Syrian refugees, proved to be statistically significant $(\mathrm{F}=4.36)(\mathrm{p}=0.005)$. The addition of patriotism, religious commitment and internationalism to the model results in a significant change in the proportion of the variance $(\mathrm{F}=3.03)(\mathrm{p}=0.008)$. This result proves that the predictors in the second set (patriotism, religious commitment and internationalism), in a group, also influence Jordanians' attitudes toward Syrian refugees even when the influence of demographic variables is controlled for. More specifically, demographic variables, namely, income, geographic location, and gender, explained as predictors in one block, $6.6 \%$ of the total variance in locals' attitudes toward Syrian refugees in Jordan. The incremental contribution of patriotism, religious commitment and internationalism explained $9.1 \%$ of the variance in Jordanians' attitudes toward increasingly protracted Syrian refugees.

Table 4. Regression on Jordanians' attitude toward Syrian refugees

\begin{tabular}{lcc}
\hline \multicolumn{1}{c}{ Predictors } & $\beta$ & Sig. \\
\hline Income & 0.13 & 0.08 \\
Geographic Location & 0.20 & 0.01 \\
Gender & 0.01 & 0.91 \\
Patriotism & 0.15 & 0.05 \\
Religious commitment & 0.38 & 0.63 \\
Internationalism & -0.05 & 0.50 \\
\hline
\end{tabular}

Model 1(Demographics): $\mathrm{F}=4.36, \mathrm{p}=0.005$ where $*$, and $* *$ represent statistical significance at 0.05 , and 0.01 respectively. $\mathrm{R}^{2}=0.066, \Delta \mathrm{R}^{2}=0.051$. Model 2 (Demographics, patriotism, religious commitment and internationalism): $\mathrm{F}=3.03, \mathrm{p}=0.008$ where $*$, and $* *$ represent statistical significance at 0.05 , and 0.01 respectively. $\mathrm{R}^{2}=0.091, \Delta \mathrm{R}^{2}=0.061$

Regarding the relative importance of each independent variable, income, geographical location and patriotism were found to have statistically significant influence on Jordanians' attitude toward Syrian refugees. Geographical location is the strongest predictor of Jordanians' attitudes toward Syrian refugees. Patriotism comes second followed by income in terms of predicting Jordanians' attitudes toward Syrian refugees. Alternatively, the results showed that gender, religious commitment and internationalism proved to be not statistically significant on Jordanians' less favorable attitude toward Syrian refugees.

With regard to the hypotheses tested, statistical analysis supported H1, H4 and H5. However, H2, H3 and H6 have been rejected. Results from this study yielded that Jordanians who live in the north of the country, where the majority of Syrian refugees are concentrated in the northern cities of Irbid, Ramtha, and Mafraq hold more negative views toward Syrian refugees than Jordanians who live in Amman where Syrian refugees represent only about 7 per cent of the total population of Amman (Stave and Hillesund, 2015). This result agrees with Crawley et al. (2013) that geographical location predicts attitudes toward refugees and people living. Additionally, this finding agrees with what Kreibaum's (2016) found that locals who are living next to/with displaced refugees complained about the negative effect of refugees on their economic situation. Jordanians with high level of patriotism expressed more 
negative attitudes toward Syrian refugees than Jordanians with low level of patriotism. This results agrees O'rourke and Sinnott (2006) who found that patriotic sentiment is a significant strong positive predictor of hosts' attitudes toward refugees, and agrees with Haslam and Pedersen's (2007) finding that patriotic individuals hold less favorable views toward refugee. High income Jordanians hold more negative attitudes toward Syrian refugees than low income Jordanians. This finding is consistent with those of Murray and Marx (2013) who found that disadvantaged and low income hosts are usually perceive refugees as threat, and Boeshaar (2016) who revealed that income is a statistical significant negative determinant of attitudes toward refugees.

There were no statistically significant associations between Jordanians' attitudes toward Syrian refugees and gender, internationalist feelings and religiosity. Specifically, Jordanians' attitudes toward Syrian refugees did not differ by gender, internationalism feelings, or religious commitment. This results agrees Boeshaar (2016) who concluded that gender is not a statistical significant predictor of hosts' attitudes toward refugees. Moreover, the results of this study disagree with Karasawa (2002) who concluded that internationalists express low negative sentiments towards out-groups including refugees and disagrees with Schlueter and Scheepers's (2010) findings that religiosity motivates individuals to perceive out-group as a threat. Despite Muslim religious leaders (imams) play a vital role in Muslim community outreach and have an enormous amount of influence and impact on their communities and followers and can (Kira et al., 2014), Jordanians with high religious identification did not express more favorable attitudes toward Syrian refugees.

The respondents were asked to indicate "the main positive/negative contributions, for Syrian refugees, to Jordan's society (based on their personal experience)" in an open question. Results are depicted in Table 5 and Table 6. Altogether, approximately, $11 \%$ of the respondents believed that hosting Syrian refugees benefits Jordan and Jordanians through improving the country's positive image among other Arab countries, and an additional $7.9 \%$ of the respondents indicated that hosting displaced Syrians improve Jordan's positive global image. Similarly to the results of survey's open ended question, face-to-face personal interviews' results confirmed that Jordanians believed that hosting Syrian refugees enhances their own country's image. For instance, one of the interviewees stated that:

Syrians are our brothers, they have been forced out of their country during the most brutal civil war human has ever known; little kids; (pause for 10 seconds); old men, old women, and so on are fleeing their country due to this ugly war; we in Jordan have only one option to open our doors for them and to share our homes, food, water for them, they are Arabs and Muslims; where they can go? (tell me) where they can go? Hosting them gives us a good name in front of our other Arab brothers (Eyad, 47, Amman).

In the same light, another interviewee said that:

I live just at the Jordan-Syria border and actually I can see the kids and women and the old men at the time they get to the country, you cannot imagine how sad that! Kids holding their moms and their milk bottles; old men and women look so depressed; disable kids and and and; so you think it is about jobs and food and cleanness? Answer me please! (asked the 'interviewer') please answer! I will tell you it is not about jobs it is about the lives of those kids. And I believe personally hosting them is good for our economy and for our country's image (Tamim, 35, Irbid).

Table 5. Syrian refugees' positive influence on Jordan (open question)

\begin{tabular}{lccc}
\hline \multicolumn{1}{c}{ Issue } & Number & Percentage \\
\hline Present Jordan as a good example for Arab & 20 & $10.5 \%$ \\
brotherhood & & 15 & \\
Good publicity for Jordan worldwide & 14 & $7.9 \%$ \\
Better food varieties & 12 & $7.3 \%$ \\
More cultural variety in Jordan & 11 & $6.3 \%$ \\
More investment & 10 & $5.8 \%$ \\
Present Jordanians as generous people & 8 & $5.2 \%$ \\
Skillful workers & & $4.2 \%$ \\
\hline
\end{tabular}

The results (Table 6) clearly show that Jordanians care more about jobs and unemployment when it comes to their attitudes regarding Syrian refugees' negative contribution to Jordan's society. About $63 \%$ of the respondents believed 
that hosting Syrian refugees takes locals' jobs and raise the unemployment rate in Jordan. This finding is consistent with those of Murray and Marx (2013) and Mabiso et al. (2014) but differs from the study of Whitaker (2002) and Landau (2004) who found that many hosts profit from job opportunities as a result of refugee presence. Approximately, $10 \%$ of the respondents believed that Syrian refugees cause prices to raise and an additional 5\% of the respondents linked the influx of Syrian refugees to the hike in home rental prices. This fining agrees with Zetter (2012) and Alix-Garcia et al. (2012) who found that large influx of refugees pushes up domestic prices of many products and services such as food prices. On this point, one of the interviewees stated that:

Most of homes' rental prices increased sharply after Syrians have come to Jordan; you have to pay about JD 250 for a two-room home in Irbid. That is too much; it is really too much! But a good things about the Syrians that I bought last winter a heater with only JD 15 and a quality blanket for only JD 10; that is too cheap; many Syrians sell aid items they receive at very low prices because they need cash" (Fareeda, 65, Irbid).

Table 6. Syrian refugees' negative influence on Jordan (open question)

\begin{tabular}{lcc}
\hline \multicolumn{1}{c}{ Issue } & Number & Percentage \\
\hline Unemployment & 120 & $62.8 \%$ \\
Higher prices & 21 & $11.0 \%$ \\
Traffic jam & 18 & $9.4 \%$ \\
Massive population growth & 16 & $8.4 \%$ \\
Higher housing rental prices & 15 & $7.9 \%$ \\
Begging & 13 & $6.8 \%$ \\
Less marriage chances for local Jordanian girls & 9 & $4.7 \%$ \\
Higher pressure on Jordan's resources & 8 & $4.2 \%$ \\
Dirt on public streets and areas & 7 & $3.7 \%$ \\
Higher pressure on housing & 7 & $3.7 \%$ \\
Pressure on health care sector & 5 & $2.6 \%$ \\
Crime & 4 & $2.1 \%$ \\
Higher pressure on water resources & 3 & $1.6 \%$ \\
Uncultured refugees & 2 & $1.1 \%$ \\
Higher pressure on Jordan's educational resources & 2 & $1.1 \%$ \\
\hline
\end{tabular}

About $8 \%$ of the respondents blamed Syrian refugees for the massive population growth in Jordan which causes significant stress on their country's capacities. In this context, one of the interviewees stated that:

Irbid was so beautiful and clean city and particularly the University Area (the southern area of the city), now it is so crowded and it is so dirty; many of Irbid City residents (including taxi drivers) call the southern area of the city "Daraa" (the largest city in South of Syria) because the majority of people who live at this part of the city are Syrians (Kamal, 70, Irbid).

Overall, this result agrees previous research findings that the presence of a large refugee population resulted in extreme pressure and demand on basic services such as housing (Achilli, 2015; Al-Kilani, 2014; Haddadin, 2016; Martin, 2005). Interestingly, 4.7\% of subjects stated that female Syrian refugees caused problems for their local Jordanian females when it comes to marriage as some Jordanians prefer to marry Syrian females (marrying a Syrian female is much cheaper than marrying a Jordanian female. Liana, 31, Amman said that:

You know even Jordanian girls are in a very big trouble; young Jordanian male pay less Mah-her (local word for dowry) to get married Syrian girls, and actually they are more beautiful than local girls. But, but, I mean.... that influences Jordanian girls' chances to get married.

Generally, the protracted nature of the Syrian civil war and its increasingly negative impact on Jordan's economy changed the positive mode most Jordanians hold toward the mega influx of Syrian refugees to Jordan. Results from both qualitative and quantitative analyses yielded economic perceptions and jobs shape the negative public sentiment 
toward Syrians attitudes toward Syrian refugees in Jordan. The results concluded that Jordanian who live in the North of country (where most of Syrian refugees live), high income Jordanians and patriotic Jordanians express less favorable attitudes toward Syrian refugees. Despite the current study extended previous scholarship on hosts' views toward displaced refugees by exploring Jordanians' negative attitudes toward displaced Syrian refugees in Jordan, a country that has one of the highest numbers of refugees per capita all over the world, the current work is not without its limitations. Sample size was small. Future studies should attain larger samples and should include Jordanian subjects from the south of the country. It will be interesting to explore the positive/negative contribution of Syrians to local society in Jordan from the Syrian refugees' perspective themselves. Also, it will be interesting to explore Syrian refugees' attitudes towards their Jordanian hosts and to examine how their attitudes are determined by demographic variables (income, education, living inside a refugees camp/living outside a refugee camp, living in the north of the country/living in Amman city, and gender) and socio-psychological variables (religious commitment, Arab ethnic feelings). Overall, there is limited empirical data on hosts' attitudes toward refugees. Understanding how refugees are perceived by hosts enhances intergroup relations and helps to promote harmony between host groups and refugees. Despite its limitations, the present investigation was designed to expand the aforementioned work on the hosts' attitudes' toward refugees.

\section{References}

Achilli, L. (2015). Syrian refugees in Jordan: a reality check. The Migration Policy Centre-the European University Institute, Florence, Italy.

Agblorti, S. K. (2011). Refugee integration in Ghana: The host community's perspective. New issues in refugee research paper, 203.

Al Ganideh, S. F., \& Good, L. K. (2015). Understanding abusive child labor practices in the shadow of the Arab spring. Journal of Children's Services, 10(1), 76-91.

Ali, T. M. (2014). Post-political transitions in Arab spring countries: The challenges. Procedia-Social and Behavioral Sciences, 109, 250-256.

Alix-Garcia, J., \& Saah, D. (2010). The effect of refugee inflows on host communities: Evidence from Tanzania. The World Bank Economic Review, 24(1), 148-170.

Alix-Garcia, J., Bartlett, A., \& Saah, D. (2012). Displaced populations, humanitarian assistance and hosts: A framework for analyzing impacts on semi-urban households. World Development, 40(2), 373-386.

Al-Kilani, S. (2014). A duty and a burden on Jordan. Forced Migration Review, (47), 30-31.

Al-Qdah, T., \& Lacroix, M. (2011). Iraqi refugees in Jordan: Lessons for practice with refugees globally. International Social Work, 54(4), 521-534.

Arnett, J. J. (2002). The psychology of globalization. American Psychologist, 57, 774-783.

Baez, J. E. (2011). Civil wars beyond their borders: The human capital and health consequences of hosting refugees. Journal of Development Economics, 96(2), 391-408.

Batson, C. D., Anderson, S. L., \& Collins, E. (2005). Personal religion and prosocial motivation. In M. L. Maher and S. A. Karabenick (Eds.), Motivation and religion (14, special issue, 151-185). Advances in Motivation and Achievement.

Bayat, A. (2015). Plebeians of the Arab Spring. Current Anthropology, 56(S11), S33-S43.

Black, R., \& Sessay, M. F. (1997). Forced migration, environmental change and woodfuel issues in the Senegal River Valley. Environmental Conservation, 24(03), 251-260.

Boeshaar, C. Q. (2016). Do Europeans' perceived income levels affect their attitudes towards immigrants? A regression analysis of individual self-reported comfort in income vis a vis attitudes towards immigration using the European social survey. A Thesis submitted to the Faculty of the Graduate School of Arts and Sciences of Georgetown University.

Chatelard. G. (2010). Jordan: A Refugee Haven. Retrieved from https://halshs.archives-ouvertes.fr/halshs-00514403

Cohen, R. (2015). Germany, Refugee Nation. New York Times, Dec 21, 2015. Retrieved from http://www.nytimes.com/

Collis, J., \& Hussey, R. (2013). Business research: A practical guide for undergraduate and postgraduate students. Palgrave MacMillan: London. 
Crawley, H., Drinkwater, S., \& Kauser, R. (2013). Regional variations in attitudes towards refugees: evidence from Great Britain. (No. 1326). Centre for Research and Analysis of Migration (CReAM), Department of Economics, University College London.

Cumming-Bruce, N. (2015). Number of Syrian Refugees Climbs to More Than 4 Million. New York Times, July 9, 2015. Retrieved from http://www.nytimes.com/

De Bel-Air, F. (2009). Iraqis in Jordan since 2003: What Socio-political Stakes? CARIM Research Reports 2009/10. San Domenico di Fiesole: Robert Schuman Centre for Advanced Studies.

De Montclos, M. A. P., \& Kagwanja, P. M. (2000). Refugee camps or cities? The socio-economic dynamics of the Dadaab and Kakuma camps in Northern Kenya. Journal of refugee studies, 13(2), 205-222.

Doocy, S., Sirois, A., Anderson, J., Tileva, M., Biermann, E., Storey, J. D., \& Burnham, G. (2011). Food security and humanitarian assistance among displaced Iraqi populations in Jordan and Syria. Social Science \& Medicine, 72(2), 273-282.

Druckman, D. (1994). Nationalism, patriotism, and group loyalty: A social psychological perspective. Mershon International Studies Review, 43-68.

Duriez, B. (2004). Are religious people nicer people? Taking a closer look at the religion-empathy relationship. Mental Health, Religion \& Culture, 7(3), 249-254.

Ek, R., \& Karadawi, A. (1991). Implications of refugee flows on political stability in the Sudan. Ambio, 196-203.

Fagen, P. W. (2009). Iraqi Refugees: seeking stability in Syria and Jordan. CIRS Occasional Papers.

Fargues, P., \& Fandrich, C. (2012). Migration after the Arab Spring. European University Institute. Robert Schuman Centre for Advanced Studies. San Domenico di Fiesole, Italy.

Ghauri, P., \& Gronhaug, K. (2002). Research methods in business studies: A practical guide. Harlow: Financial Times Prentice Hall.

Guzansky, Y., \& Berti, B. (2014). Is the New Middle East Stuck in Its Sectarian Past? The Unspoken Dimension of the "Arab Spring". Orbis, 57(1), 135-151.

Haddadin, S. (2016). JD 1.5 Billion the cost of Health Services Offered to Syrians. Alrai Newspaper, No. 16564, p.6

Hair, J., Jr., Anderson, R., Tatham, R. L., \& Black, W. (2006). Multivariate Data Analysis. Prentice Hall: Englewood Cliffs, NJ.

Hakovirta, H. (1993). The global refugee problem: a model and its application. International Political Science Review, 14(1), 35-57.

Haslam, N. I. C. K., \& Pedersen, A. N. N. E. (2007). Attitudes towards asylum seekers: the psychology of exclusion. Yearning to breathe free: Seeking asylum in Australia, 208-218.

Jacobsen, K. (1996). Factors influencing the policy responses of host governments to mass refugee influxes. International Migration Review, 30(3), 655-678.

Jacobsen, K. (2002). Can refugees benefit the state? Refugee resources and African statebuilding. The Journal of Modern African Studies, 40(4), 577-596.

Jordan Department of Statistics (JDOS). (2016). The Results of 2015 Population and Housing Census. Feb, 2016, $1-70$.

Karasawa, M. (2002). Patriotism, nationalism, and internationalism among Japanese citizens: An epicemic approach. Political Psychology, 23(4), 645-666.

Khawaja, M. (2003). Migration and the reproduction of poverty: the refugee camps in Jordan. International Migration, 41(2), 27-57.

Kira, I. A., Amer, M. M., \& Wrobel, N. H. (2014). Arab refugees: Trauma, resilience, and recovery. In Biopsychosocial Perspectives on Arab Americans (pp. 175-195). Springer US.

Knoll, B. R. (2009). “And who is my neighbor?” Religion and immigration policy attitudes. Journal for the Scientific Study of Religion, 48(2), 313-331.

Kosterman, R., \& Feshbach, S. (1989). Toward a measure of patriotic and nationalistic attitudes. Political Psychology, 257-274. 
Kreibaum, M. (2016). Their Suffering, Our Burden? How Congolese Refugees Affect the Ugandan Population. World Development, 78, 262-287.

Landau, L. B. (2004). Challenge without transformation: refugees, aid and trade in western Tanzania. The Journal of Modern African Studies, 42(1), 31-59.

Lee, W. N., Hong, J. Y., \& Lee, S. J. (2003). Communicating with American consumers in the post 9/11 climate: An empirical investigation of consumer ethnocentrism in the United States. International Journal of Advertising, 22(4), 487-510.

Lischer, S. K. (2008). Security and displacement in Iraq: responding to the forced migration crisis. International Security, 33(2), 95-119.

Mabiso, A., Maystadt, J. F., Vandercasteelen, J., \& Hirvonen, K. (2014). Refugees, food security, and resilience in host communities: Transitioning from humanitarian assistance to development in protracted refugee situations, 2 , 1-40. International Food Policy Research Institute (IFPRI).

Martin, A. (2005). Environmental conflict between refugee and host communities. Journal of Peace Research, 42(3), 329-346.

McKay, F. H., Thomas, S. L., \& Kneebone, S. (2012). 'It would be okay if they came through the proper channels': Community perceptions and attitudes toward asylum seekers in Australia. Journal of Refugee Studies, 25(1), 113-133.

Meertens, R. W., \& Pettigrew, T. F. (1997). Is subtle prejudice really prejudice?. Public Opinion Quarterly, 61, 54-71.

Moore, W. H., \& Shellman, S. M. (2007). Whither will they go? A global study of refugees' destinations, 1965-1995. International Studies Quarterly, 51(4), 811-834.

Mummendey, A., Klink, A., \& Brown, R. (2001). Nationalism and patriotism: National identification and out-group rejection. British Journal of Social Psychology, 40(2), 159-71.

Murray, K. E., \& Marx, D. M. (2013). Attitudes toward unauthorized immigrants, authorized immigrants, and refugees. Cultural Diversity and Ethnic Minority Psychology, 19(3), 332.

Neumayer, E. (2004). Asylum Destination Choice What Makes Some West European Countries More Attractive Than Others?. European Union Politics, 5(2), 155-180.

Neumayer, E. (2005). Bogus refugees? The determinants of asylum migration to Western Europe. International Studies Quarterly, 49(3), 389-410.

O'rourke, K. H., \& Sinnott, R. (2006). The determinants of individual attitudes towards immigration. European Journal of Political Economy, 22(4), 838-861.

Pedersen, A., \& Walker, I. (1997). Prejudice against Australian Aborigines: Old-fashioned and modern forms. European Journal of Social Psychology, 27(5), 561-587.

Pedersen, A., Attwell, J., \& Heveli, D. (2005). Prediction of negative attitudes toward Australian asylum seekers: False beliefs, nationalism, and self-esteem. Australian Journal of Psychology, 57(3), 148-160.

Pedersen, A., Clarke, S., Dudgeon, P., \& Griffiths, B. (2005). Attitudes toward Indigenous Australians and asylum seekers: The role of false beliefs and other social-psychological variables. Australian Psychologist, 40(3), 170-178.

Rahman, M. S. (2012). Young consumers' perception on foreign made fast moving consumer goods: The role of religiosity, spirituality and animosity. International Journal of Business and Management Science, 5(2), 103-118.

Sampson, D., \& Smith, H. (1957). A scale to measure world-minded attitudes. The Journal of Social Psychology, 45, 99-106.

Saroglou, V. (2006). Religion's role in prosocial behavior: Myth or reality?. Religion, 31(2), 1-66.

Schlueter, E., \& Scheepers, P. (2010). The relationship between outgroup size and anti-outgroup attitudes: A theoretical synthesis and empirical test of group threat-and intergroup contact theory. Social Science Research, $39(2), 285-295$.

Schmeidl, S. (1997). Exploring the causes of forced migration: A pooled time-series analysis, 1971-1990. Social 
Science Quarterly, 78(2), 284-308.

Schweitzer, R., Perkoulidis, S., Krome, S., Ludlow, C., \& Ryan, M. (2005). Attitudes towards refugees: The dark side of prejudice in Australia. Australian Journal of Psychology, 57(3), 170-179.

Shiblak, A. (1996). Residency status and civil rights of Palestinian refugees in Arab countries. Journal of Palestine Studies, 25(3), 36-45

Skelton, M. (2015). International Mindedness and the Brain: The Difficulties of 'Becoming'. In M. Hayden, J. Levy \& J. Thompson (Eds.), The Sage Handbook of Research in International Education (pp. 73-87). London: Sage.

Stave, S. E., \& Hillesund, S. (2015). Impact of Syrian refugees on the Jordanian labour market. ILO.

Stein, B. N. (1986). The experience of being a refugee: Insights from the research literature. Refugee Mental Health in Resettlement Countries, 5-23.

Stephan, W. G., \& Mealy, M. D. (2011). Intergroup threat theory. The Encyclopedia of Peace Psychology.

Stephan, W. G., \& Renfro, C. L. (2002). The role of threat in intergroup relations. From Prejudice to Intergroup Emotions: Differentiated Reactions to Social Groups, 11,191-207.

Sumner, W. G. (1906). Folkways: A study of the sociological importance of usages, manners, customs, mores, and morals. New York: Ginn.

The Jordan Times. (2016, March, 29). Syrian Refugees Offered Full Range of Subsidized Medical Services. The Jordan Times. 41(12293), 13.

Türken, S., \& Rudmin, F. W. (2013). On psychological effects of globalization: Development of a scale of global identity. Psychology \& Society, 5(2), 63-89.

Ullah, A. A. (2011). Rohingya refugees to Bangladesh: Historical exclusions and contemporary marginalization. Journal of Immigrant \& Refugee Studies, 9(2), 139-161.

UNHCR. (2013). UNHCR: Two million Syrians are refugees. 3 September 2013. Retrieved from http://www.unhcr.org/

UNHCR. (2014). UNHCR Statistical Yearbook 2014. Retrieved from http://www.unhcr.org/56655f4e0.pdf

UNHCR. (2016). Retrieved from http://data.unhcr.org/syrianrefugees/settlement.php?id=176\&region=77\&country=107

Verkuyten, M. (2007). Religious group identification and inter-religious relations: A study among Turkish-Dutch Muslims. Group processes \& Intergroup Relations, 10(3), 341-357.

Whitaker, B. E. (2002). Refugees in Western Tanzania: The distribution of burdens and benefits among local hosts. Journal of Refugee Studies, 15(4), 339-358.

Wilson, T. C. (2001). Americans' views on immigration policy: Testing the role of threatened group interests. Sociological Perspectives, 44(4), 485-501.

Worthington, Jr, E. L., Nathaniel, G. W., Terry, L. H., Jennifer, S. R., Michael, E. M., Jack, W. B., ... Lynn, O. (2003). The Religious Commitment Inventory--10: Development, refinement, and validation of a brief scale for research and counseling. Journal of Counseling Psychology, 50(1), 84-96.

Zetter, R. (2012). Are refugees an economic burden or benefit?. Forced Migration Review, (41), 50. 